\title{
Therapeutic potential of interleukin-15 in cancer (Review)
}

\author{
GHEORGHITA ISVORANU ${ }^{1}$, MIHAELA SURCEL ${ }^{2}$, ADRIANA NARCISA MUNTEANU ${ }^{2,3}$, \\ OVIDIU GABRIEL BRATU ${ }^{4-6}$, FLORENTINA IONITA-RADU ${ }^{7}$, \\ MONICA TEODORA NEAGU ${ }^{2,3}$ and MARIOARA CHIRITOIU-BUTNARU ${ }^{8}$ \\ Departments of ${ }^{1}$ Animal Husbandry and ${ }^{2}$ Immunology, 'Victor Babes' National Institute of Pathology, 050096 Bucharest; \\ ${ }^{3}$ Doctoral School of Biology, Faculty of Biology, University of Bucharest, 050095 Bucharest; \\ ${ }^{4}$ Clinical Department III, 'Carol Davila' University of Medicine and Pharmacy, 020021 Bucharest; \\ ${ }^{5}$ Clinic of Urology, 'Dr. Carol Davila' University Emergency Central Military Hospital, 010825 Bucharest; \\ ${ }^{6}$ Academy of Romanian Scientists, 050094 Bucharest; ${ }^{7}$ Department of Gastroenterology, 'Dr. Carol Davila' University \\ Emergency Central Military Hospital, 010825 Bucharest; ${ }^{8}$ Department of Molecular Cell Biology, \\ Institute of Biochemistry of The Romanian Academy (IBAR), 060031 Bucharest, Romania
}

Received January 25, 2021; Accepted February 24, 2021

DOI: $10.3892 /$ etm.2021.10107

\begin{abstract}
The immune system is dysfunctional in cancer, and therapeutic approaches designated to restore immunity and increase long-term overall survival are desirable. The role of immunotherapy is to trigger the immune system to recognize and destroy tumor cells. Interleukin-15 (IL-15) is a member of the common gamma-chain $(\gamma c)$ cytokines that promote the differentiation and expansion of T cells, B cells and natural killer (NK) cells, leading to enhanced antitumor responses. This suggests that IL-15 is a promising candidate for anticancer therapy. Renewed interest in cancer immunotherapy has led to an increased number of preclinical studies and clinical trials that have investigated the reliability and potency of IL-15-based agents, not only as single therapy, but also in combination with others. This review provides a description of these studies which show the advantages and disadvantages of IL-15 as an immunotherapeutic agent. We present here the role of IL-15 and pharmacologically improved IL-15 superagonists as a single treatment or in combination with other therapeutic agents.
\end{abstract}

\section{Contents}

1. Introduction

2. Interleukin-15

3. Interleukin-15 and preclinical studies

4. Interleukin-15 and clinical trials

5. Conclusions

Correspondence to: Dr Gheorghita Isvoranu, Department of Animal Husbandry, 'Victor Babes' National Institute of Pathology, 99-101 Splaiul Independentei, 050096 Bucharest, Romania

E-mail: gina_isvoranu@yahoo.com

Key words: interleukin-15, cancer immunotherapy, combination immunotherapy, natural killer cells, T cells

\section{Introduction}

Cancer remains one of the main causes of mortality despite all efforts to decode the molecular mechanisms of the disease and to develop therapeutic strategies (1). Currently, there are three main approaches to treating cancer patients: Surgery, radiotherapy and chemotherapy. These three therapeutic approaches are named by the experts as 'the pillars of cancer therapy', but more and more oncologists are considering immunotherapy as 'the fourth pillar' (2). Immunotherapy either stimulates the activities of specific components of the immune system, or counteracts the signals produced by tumor cells which suppress the immune response. The concept of single therapy in cancer therapy has been discounted with each discovery related to the genetic and immunologic complexity of the tumor microenvironment (3-5). Currently, many studies have focused on increasing the effectiveness of antitumor therapy by combining established cancer treatment, such as chemotherapy, radiotherapy and photodynamic therapy with immunotherapy. Many efforts are also being made to identify new immune therapeutic targets and combinations of immunotherapeutic agents for increasing the response rates to therapies.

Immunotherapy began with the use of Coley's toxins in the treatment of osteosarcoma and has expanded to cytokines such as interleukin-2 (IL-2) and interferon- $\gamma$ (IFN $\gamma$ ) to recently immune checkpoint inhibitors, anti-programmed cell death 1/programmed death ligand 1 (anti-PD-1/PD-L1) and cytotoxic T-lymphocyte antigen-4 (anti-CTLA-4) (6). Immunotherapy in cancer comprises immune system modulators (cytokines), therapeutic antibodies, immune cell therapy, immune checkpoint inhibitors, and vaccines (7).

In the last four decades, cytokines have been explored in large-scale clinical trials for patients with melanoma, renal cell cancer (RCC), breast cancer, glioblastoma, lymphoma, and leukemia (8). US Food and Drug Administration (FDA) has approved several cytokines and hematopoietic growth factors for adjuvant therapy in cancer. Interferon-alpha (IFN- $\alpha$ ) 
and IL-2 are used in the treatment of RCC and metastatic melanoma, or as adjuvant therapy for patients with surgical excision of high-risk malignant melanoma (9). There are many studies that have reported a significant alteration of $\mathrm{T}$ and NK cell functions in cancer (10-12). The combination of IL-2 with adoptive T cell therapy has significantly improved treatment efficacy. These achievements indicate that stimulation of T and NK cell reactions may produce efficacious and lasting responses $(13,14)$. Cytokines are immunomodulators; they act on both effector and cytotoxic cells. Various animal tumor models have demonstrated a wide antitumor activity for different cytokines $(15,16)$. Various cytokines, such as granulocyte-macrophage colony-stimulating factor (GM-CSF), and interleukins, IL-2, IL-15, IL-12, IL-18, IL-7 and IL-21, have been clinically evaluated in patients with advanced forms of cancer (9).

One of the most hopeful immunotherapeutic agents in cancer is IL-15, a cytokine which shares similar functions with IL-2, such as the potential to stimulate antitumor responses. Yet, it also has clear advantages over IL-2 (17). The National Cancer Institute (NCI) ranked IL-15 among the top 20 immunotherapeutic agents in cancer therapy over a decade ago. Since IL-15 was discovered, there have been more than 6,000 papers and more than 170 clinical trials involving this cytokine (18).

In the present review, we offer an image of both preclinical and clinical studies which propose IL-15 as an effective antitumor agent.

\section{Interleukin-15}

IL-15 plays an important role in innate and adaptive immunity. It is a four-helix bundle cytokine, and was discovered in 1994 by two different research groups $(19,20)$. It was described as a $\mathrm{T}$ cell proliferation factor which shared IL-2 receptor $\beta$ subunit with IL-2. IL-15 is a pleiotropic cytokine, constitutively expressed by many type of cells such as macrophages, monocytes, dendritic cells (DCs), T cells, as well as epithelial cells, fibroblasts, keratinocytes, and nerve cells. However, IL-15 is mainly produced by macrophages, monocytes and DCs (21).

IL-15 is especially involved in lymphocyte and NK cell functioning and homeostasis. IL-15 signals through a heterotrimeric receptor which consist of three subunits, the IL-15 receptor $\alpha$ (IL-15R $\alpha$ or CD215) specific subunit, IL2/IL-15 receptor $\beta$ subunit (IL2/IL-15R $\beta$ ), and $\gamma$ (CD132) subunit, a common chain for other cytokines such as IL-2, IL-4, IL-7, IL-9, and IL-21. After activation, myeloid cells produce IL-15 as a membrane-bound heterodimer complexed with IL-15R $\alpha$, and it is dominantly trans-presented to the cells expressing the dimeric IL2/IL-15R $\beta \gamma$ receptor (22). IL-15 signaling requires Janus kinases (Jak)-1 and Jak-3 to phosphorylate and activate the signal transducer and activator of transcription (STAT) 3 and STAT5. Furthermore, IL-15 stimulates both the phosphatidylinositol 3-kinase/protein kinase B (PI3K/AKT) and RAS/mitogen-activated protein kinase (RAS/MAPK) pathways (23). IL-15 acts on many cells of the immune system, being able to increase proliferation of $\mathrm{B}$ cells and secretion of immunoglobulins, and is critical for the ontogeny of NK and $\mathrm{CD}^{+} \mathrm{T}$ cells, inducing cell activation, proliferation, cytolytic activity and the production of cytokines such as interferon- $\gamma($ IFN- $\gamma)$ by these cells. Although IL-2 and IL-15 present many similar functions on lymphocytes, there are some differences. IL-15 does not exert significant effects on regulatory $\mathrm{T}$ cells (Tregs), a subset of cells that inhibit antitumor immunity and promote tumor development and progression; and by acting as a survival factor of CD8 memory T cells, it plays an important role in supporting the long-term maintenance, high-avidity $\mathrm{T}$ cell responses to malignant cells $(24,25)$.

Unfortunately, IL-15 exhibits a dark side. This cytokine also presents pro-inflammatory potential, being involved in the pathogenesis of several autoimmune diseases. IL-15 induces production of pro-inflammatory cytokines, such as IL-1 $\beta$ and tumor-necrosis factor- $\alpha$ (TNF $\alpha$ ), and promotes the survival of a self-directed memory $\mathrm{T}$ cell subpopulation (26). IL-15 has been detected in patients with such autoimmune diseases as inflammatory bowel disease $(27,28)$, rheumatoid arthritis $(29,30)$, and multiple sclerosis (MS) $(31,32)$. In these patients, both elevated level of IL-15 in body fluids and disordered IL-15 expression has been noted when compared with healthy controls.

\section{Interleukin-15 and preclinical studies}

IL-15 is a cytokine that stimulates proliferation, activation and expansion of NK cells, as well as T-cell proliferation and generation of cytotoxic $\mathrm{T}$ lymphocytes, and sustaining of long-lasting antitumor immunity $(18,33,34)$. Under normal conditions, soluble IL-15 (sIL-15) is difficult to be found in vivo, mainly due to its short half-life and the strict regulatory mechanisms involved in its expression. However, the first studies which assessed the potential immunotherapeutic role of this cytokine used the soluble form $(35,36)$. Preclinical observations revealed that recombinant IL-15 (rIL-15) also generated long-term proliferation and activation of CD8 memory $\mathrm{T}$ and NK cells. This ability of IL-15 to stimulate these cytotoxic effector cells is the major mechanism which supports its potential antitumor activity (18). Several preclinical studies have shown that administration of rIL-15 leads to tumor regression, metastasis reduction, and increased survival in tumor-bearing mice (33). When using in vivo studies on mice, the increased antitumor response was linked to enriched cytotoxic activities of T-CD8 ${ }^{+}$ and NK cells. Thus, in some mice which received IL-15 treatment, the tumors were removed and the treated animals continued to be tumor-free after re-challenge, suggesting that a long-term immune response had occurred $(21,34)$.

Administration of IL-15 alone showed antitumor effects in some mouse tumor models, but co-administration of IL-15 with soluble IL-15R $\alpha$ (sIL-15R $\alpha$ ) induced a greater antitumor response compared to IL-15 alone. The authors demonstrated that administration of IL-15/sIL-15R $\alpha$ mimics trans-presentation and increases the bio-stability of this cytokine $(37,38)$. Moreover, co-administration of IL-15 with IL-21 was found to enrich the antitumor effectiveness of IL-15 in a mouse tumor model (39). Furthermore, IL-15 along with another two cytokines, IL-12 and IL-18, induced differentiation of cytokine-induced memory-like NK cells which demonstrated a vigorous antitumor response $(1,40)$.

Targeted therapy using monoclonal antibodies (mAbs) has been established as one of the most successful therapeutic strategy for cancer; one of the mechanisms of action being antibody-dependent cellular cytotoxicity (ADCC) for 
elimination of the tumor cells. Combination of IL-15 with mAbs, anti-CD20 (rituximab) or anti-CD52 (alemtuzumab), increased the effectiveness of the treatment in some forms of blood cancer, and the antitumor effects relied on elevated ADCC (41).

During the last few years, the use of CD40 agonists in cancer therapy has been investigated thoroughly, both as a single intervention or in combination with others, such as checkpoint inhibitors PD-1 and CTLA-4 $(42,43)$. Both in mice and humans, treatment strategies utilizing CD40 agonists with or without checkpoint inhibitors have revealed more robust antitumor activity featured by major tumor regression and a durable response $(44,45)$. In addition, in preclinical studies, CD40 agonist antibody combined with IL-15 rendered enhanced antitumor efficacy with profound increases in survival and complete recovery $(46,47)$. The antitumor effect of this therapeutic combination is based especially on T-CD8 ${ }^{+}$ and NK cells without the need for T-CD4 ${ }^{+}$cells. Additionally, a large number of $\mathrm{CD}_{103}{ }^{+} \mathrm{DCs}$ was observed (46).

The ability of DCs to initiate the adaptive immune response was explored in vaccination strategies during the past decades. Many preclinical and clinical studies have shown potent antitumor responses after treatment with DC-based vaccine $(48,49)$. In the last few years, IL-15 differentiated DCs (IL-15 DCs) have shown great interest as a new DC-based cancer vaccine (50). These IL-15 DCs have the potential to stimulate both $\mathrm{T}$ and $\mathrm{NK}$ cells, and also can have a direct cytotoxic action against tumor cells (51).

The instability of soluble IL-15 and availability in vivo of IL-15R $\alpha$ restrict its potency. Because of these limitations, a variety of IL-15/IL-15R $\alpha$ complexes, IL-15 superagonists, were generated to enhance the therapeutic capacity of this cytokine. IL-15 superagonists exhibit appreciable stability and activity in vivo, promoting a considerable activation of $\mathrm{NK}$ and T-CD8 ${ }^{+}$cells and fewer toxic effects (52-57). Currently, in clinical trials, the following IL-15 superagonists are the most used: Heterodimeric (het) IL-15, receptor-linker-IL-15 (RLI), IL-15/IL-15R $\alpha-F c$, and N-803 (previously known as ALT-803) (58). IL-15 superagonists show significant promise for use in tandem with additional immunotherapies, such as immune checkpoint inhibitors, vaccines, antitumor antibodies, and adoptive cell therapies (59).

Mortier et al generated a hyper-IL-15 fusion protein called RLI, obtained by attaching a sushi domain of IL-15R $\alpha$ to IL-15 (60). This superagonist is capable to increase the bioactivity of IL-15, and in mouse mammary carcinoma, 4T1 administration of RLI showed antimetastatic activities, having vigorous immunostimulatory properties on NK cells. In addition, RLI enhanced the antitumor activity of anti-PD-1 antagonists in murine colon carcinoma; the combination of the two therapeutic agents being stronger than IL-15 and anti-PD-1 alone (61).

Despite all of the attempts in the research of cancer immunotherapy, hardly a fraction of patients currently respond to these new therapeutic approaches. The immunosuppressive tumor microenvironment restricts both innate and adaptive antitumor responses for promoting tumor development (62). This immune suppression includes among others the expression of immune checkpoint inhibitors such as PD-1/PD-L1 and CTLA-4. Overexpression of PD-L1 is noted in many types of cancer and is related with poor clinical outcome (63). PD-L1 negatively regulates $\mathrm{T}-\mathrm{CD}^{+}$and NK cell function by restraining cell proliferation and cytokine release (64). In some tumors with a high number of mutations as melanoma, lung and bladder cancers, an increase in survival was observed after PD-L1 or PD-1 administration (65-67). An IL-15 superagonist, ALT-803, has shown in some preclinical studies antitumor efficacy against murine solid carcinomas, but was not curative $(68,69)$. Preclinical use of IL-15 superagonist $\mathrm{N}-803$ (formerly ALT-803) plus anti-PD-L1 improved survival by diminishing tumor burden and metastasis (70).

A new approach for cancer treatment is oncolytic immunotherapy. This therapy uses viruses which preferentially infect and destroy tumor cells (71). Oncolytic viruses expressing IL-15 can induce both potent oncolytic effect and activate effector immune cells for a strong antitumor response. It has been shown that a vesicular stomatitis virus which expresses IL-15 induced strong antitumor immunity in a mouse colon cancer model (72). In addition, myxoma virus that expresses IL15R $\alpha$-IL-15 fusion protein presented an augmented immune response in a B1-F10 melanoma model (73). A vaccinia virus expressing IL-15/IL-15R $\alpha$ (vvDD-IL15-Ra) combined with anti-PD1 blockade was found to provide significant antitumor activity in both colorectal and ovarian murine cancer models (74).

\section{Interleukin-15 and clinical trials}

IL-2 was the first cytokine used as an immunotherapeutic agent in cancer treatment. In 1992, the FDA approved use of IL-2 for patients with metastatic renal cell carcinoma, and for those with metastatic melanoma six years later (75). Despite the capability of high-dose IL-2 therapy to generate complete responses in patients with metastatic malignancies, significant systemic toxicity has also been observed. Beside its high toxicity, IL-2 also has the ability to induce Treg cell expansion and generate immune-suppressive responses $(25,76)$. Similar to IL-2, IL-15 has the ability to boost antitumor immune responses, but IL-15 does not sustain Treg expansion and does not exhibit such high toxicity as IL-2 (36). Some studies have shown that when IL-15 is administrated at high doses it can produce side effects, including reduced appetite, diarrhea, weight loss, without autoimmune manifestations or infections. Using IL-15 as a therapeutic agent in cancer patients was shown to promote T- and NK cell expansion, maturation and cytotoxic functions $(77,78)$. Based on these observations treatment with IL-15 is recommended as an alternative strategy for metastatic cancers.

In a first clinical trial, recombinant aglycosylated IL-15 produced in Escherichia coli was administered intravenous every day to patients with metastatic malignant melanoma and metastatic RCC. All patients showed, similar to murine studies, a peripheral proliferation of $\mathrm{T}^{-\mathrm{CD}^{+}}{ }^{+}$and $\mathrm{NK}$ cells soon after IL-15 infusion, but higher doses caused toxic effects, including high fever, neutropenia, thrombocytopenia and hypotension. These data suggest that in order to reduce toxicity it is recommended to use a continuous intravenous or subcutaneous route of administration (79).

IL-15 superagonist ALT-803 that was demonstrated to develop robust IL-15 activity in animal models, was 
administrated in combination with anti-PD-1 therapy in patients with metastatic non-small cell lung cancer. The treatment was well tolerated, without a dose-dependent toxicity, and a phase II study is in progress (80). ALT-803 plus intravesical bacillus Calmette-Guérin (BCG) was assessed in bladder cancer (81), and the FDA granted fast-track approval for this therapy for non-muscle invasive bladder cancer (82).

The effectiveness of receptor-linker-IL-15 as a single therapy or combined with a PD-1 antagonist (pembrolizumab) is under evaluation in a clinical trial (SC103) that enrolled patients with metastatic tumors (SC103) (83).

Currently, there are ongoing clinical trials involving IL-15 or pharmacologically enhanced IL-15 superagonists, most of them include administering IL-15 in combination with other agents. Combinations with mAbs, alemtuzumab (NCT02689453) or rituximab (NCT02384954), are used for testing the ability of IL-15 to increase ADCC effects in relapsed/refractory acute and chronic adult T-cell leukemia, and in relapsed/refractory indolent Non-Hodgkin lymphoma. In others, IL-15 is used as an adjuvant for adoptive NK cell therapies in children and young patients with advanced solid tumors (NCT01875601), in patients with Merkel cell carcinoma (stages III or IV) (NCT02465957), in acute myelogenous leukemia (NCT01385423), and in pancreatic cancer (NCT03329248, NCT03387098, NCT03586869 and NCT03136406) (46). Recently, patients with refractory cancers were enrolled in a clinical trial which is investigating the effects and doses of IL-15 with anti-checkpoint antibodies nivolumab and ipilimumab (NCT03388632), and a trial with rIL-15 and avelumab (anti-PD-L1) in patients with clear-cell renal carcinoma (NCT04150562) (59).

\section{Conclusions}

In the present review, we highlighted the advantages and disadvantages of IL-15 as a cancer therapeutic agent based on data acquired from preclinical studies and clinical trials. At the beginning, IL-15 denoted a significant potential for therapeutic use, because of its capacity to stimulate the proliferation and cytotoxic functions of immune effector cells. In several murine models of cancers, administration of IL-15 not only expanded the amount of cytotoxic T cells and NK cells but also enhanced their cytotoxic functions leading to robust antitumor responses. But, despite all of these promising data, the effectiveness of this cytokine is restricted by its short half-life. Different strategies have been developed to enhance the stability and effectiveness of IL-15, mostly by constructing IL-15 superagonists. All of these IL-15 superagonists were found to enhance its bioactivity and stability in vivo and subsequent enhanced antitumor immunity. In a previous study, our group also communicated that co-administration of IL-15 with the IL15R $\alpha$ subunit induced greater antitumor responses than when IL-15 was used alone (38). IL-15 administered as a monotherapy showed some efficacy in inducing tumor regression, but IL-15 used in combination with other immunotherapies revealed greater potential in the fight against cancer. Currently, therapeutic trials including IL-15 with agonistic anti-CD40, with the checkpoint inhibitors, anti-PD-L1 and anti-CTLA-4, and with cancer directed monoclonal antibodies are ongoing.

In our opinion, the main challenges of IL-15 therapy for cancer remain the optimal dose and the route of administration for maximize antitumor response with limited toxicity. In addition, another question awaiting an answer from future studies is what type of tumors are more responsive to IL-15 treatment, alone or in different combinations.

There are currently clinical trials that are assessing the therapeutic applications of IL-15 alone or in combination with other immunotherapy in numerous cancer types. All of these studies provide the hope that IL-15 will take an essential role in cancer therapy.

\section{Acknowledgements}

Not applicable.

\section{Funding}

This review was funded by the Ministry of Research and Innovation in Romania, under Program 1-Improvement of the National System of Research and Development, Subprogram 1.2-Institutional Excellence-Projects of Excellence Funding in RDI (contract nos. 7PFE/16.10.2018, 19.29.02.03 and 337PED/2020).

\section{Availability of data and materials}

All information provided in this review is documented by relevant references.

\section{Authors' contributions}

GI conceived and drafted the review. MS, ANM, OGB and FIR performed the literature search and revised the final manuscript. MTN and MCB supervised and designed the review and provided critical appreciation. All authors read and approved the final manuscript for publication.

\section{Ethics approval and consent to participate}

Not applicable.

\section{Patient consent for publication}

Not applicable.

\section{Competing interests}

The authors declare no competing interests.

\section{References}

1. Isvoranu G: The Memory Activation of NK Cells: New Methods in Cancer Immunotherapy. In: Immunotherapy-Myths, Reality, Ideas, Future. InTech, Rijeka, pp201-219, 2017.

2. McCune JS: Rapid advances in immunotherapy to treat cancer. Clin Pharmacol Ther 103: 540-544, 2018.

3. Palmer AC and Sorger PK: Combination cancer therapy can confer benefit via patient-to-patient variability without drug additivity or synergy. Cell 171: 1678-1691, 2017.

4. Marcu D, Spinu D, Mischianu D, Sorcea B, Oprea I and Bratu O: Oncological follow-up after radical prostatectomy. Rom J Mil Med 120: 39-42, 2017.

5. Popescu R, Bratu O, Spinu D, Marcu D, Farcas C, Dinu M and Mischianu D: Neuroendocrine differentiation in prostate cancer-a review. Rom J Mil Med 118: 16-19, 2015. 
6. Tormoen GW, Crittenden MR and Gough MJ: Role of the immunosuppressive microenvironment in immunotherapy. Adv Radiant Oncol 3: 520-526, 2018.

7. Zhang $\mathrm{Y}$ and Zhang Z: The history and advances in cancer immunotherapy: Understanding the characteristics of tumor-infiltrating immune cells and their therapeutic implications. Cell Mol Immunol 17: 807-821, 2020.

8. Berraondo P, Sanmamed MF, Ochoa MC,Etxeberria I, Aznar MA, Pérez-Gracia JL, Rodríguez-Ruiz ME, Ponz-Sarvise M, Castañón E and Melero I: Cytokines in clinical cancer immunotherapy. Br J Cancer 120: 6-15, 2019.

9. Lee S and Margolin K: Cytokines in cancer immunotherapy. Cancers (Basel) 3: 3856-3893, 2011.

10. Imai K, Matsuyama S, Miyake S, Suga K and Nakachi K: Natural cytotoxic activity of peripheral-blood lymphocytes and cancer incidence: An 11-year follow-up study of a general population. Lancet 356: 795-1799, 2000.

11. Thommen DS and Schumacher TN: T cell dysfunction in cancer. Cancer Cell 33: 547-562, 2018.

12. Isvoranu G, Surcel M, Huică RI, Munteanu AN, Pîrvu IR, Ciotaru D, Constantin C, Bratu O, Neagu M and Ursaciuc C: Natural killer cell monitoring in cutaneous melanoma-new dynamic biomarker. Oncol Lett 17: 4197-206, 2019.

13. Wrangle JM, Patterson A, Johnson CB, Neitzke DJ, Mehrotra S Denlinger CE, Paulos CM, Li Z, Cole DJ and Rubinstein MP. IL-2 and beyond in cancer immunotherapy. J Interferon Cytokine Res 38: 45-68, 2018

14. Farhood B, Najafi M and Mortezaee K: $\mathrm{CD}^{+}$cytotoxic T lymphocytes in cancer immunotherapy: A review. J Cell Physio 234: $8509-8521,2019$.

15. Floros T and Tarhini AA: Anticancer Cytokines: Biology and clinical effects of interferon- $\alpha 2$, interleukin (IL)-2, IL-15, IL-21, and IL-12. Semin Oncol 42: 539-548, 2015.

16. Chulpanova DS, Kitaeva KV, Green AR, Rizvanov AA and Solovyeva VV: Molecular aspects and future perspectives of cytokine-based anti-cancer immunotherapy. Front Cell Dev Biol 8: 402, 2020.

17. Cheever MA: Twelve immunotherapy drugs that could cure cancers. Immunol Rev 222: 357-368, 2008

18. Waldmann TA, Miljkovic MD and Conlon KC: Interleukin-15 (dys)regulation of lymphoid homeostasis: Implications for therapy of autoimmunity and cancer. J Exp Med 217: e20191062, 2020 .

19. Burton JD, Bamford RN, Peters C, Grant AJ, Kurys G, Goldman CK, Brennan J, Roessler E and Waldmann TA: A lymphokine, provisionally designated interleukin $\mathrm{T}$ and produced by a human adult T-cell leukemia line, stimulates T-cell proliferation and the induction of lymphokine-activated killer cells. Proc Natl Acad Sci USA 91: 4935-4939, 1994

20. Grabstein KH, Eisenman J, Shanebeck K, Rauch C Srinivasan S, Fung V, Beers C, Richardson J, Schoenborn MA, Ahdieh M, et al: Cloning of a T Cell growth factor that interacts with the beta chain of the interleukin-2 receptor. Science 264 965-968, 1994.

21. Steel JC, Waldmann TA and Morris JC: Interleukin-15 biology and its therapeutic implications in cancer. Trends Pharmacol Sci 33: 35-41, 2012.

22. Budagian V, Bulanova E, Paus R and Bulfone-Paus S: IL-15/IL-15 receptor biology: A guided tour through an expanding universe. Cytokine Growth Factor Rev 17: 259-280, 2006.

23. Mishra A, Sullivan L and Caligiuri MA: Molecular pathways: Interleukin-15 signaling in health and in cancer. Clin Cancer Res 20: 2044-2050, 2014

24. Waldmann TA: The shared and contrasting roles of interleukin-2 (IL-2) and IL-15 in the life and death of normal and neoplastic lymphocytes: Implications for cancer therapy. Cancer Immunol Res 3: 219-227, 2015.

25. Ahmadzadeh $M$ and Rosenberg SA: IL-2 administration increases $\mathrm{CD}^{+} \mathrm{CD} 25(\mathrm{hi}) \mathrm{Foxp}^{+}$regulatory $\mathrm{T}$ cells in cancer patients. Blood 107: 2409-2414, 2006.

26. Waldmann TA: Targeting the interleukin-15/interleukin-15 receptor system in inflammatory autoimmune diseases. Arthritis Res Ther 6: 174-177, 2004.

27. Kirman I and Nielsen OH: Increased numbers of interleukin-15-expressing cells in active ulcerative colitis. Am J Gastroenterol 91: $1789-1794,1996$

28. Liu Z, Geboes K, Colpaert S, D'Haens GR, Rutgeerts P and Ceuppens JL: IL-15 is highly expressed in inflammatory bowel disease and regulates local t cell-dependent cytokine production. J Immunol 164: 3608-3615, 2000.
29. Baslund B, Tvede N, Danneskiold-Samsoe B, Larsson P, Panayi G, Petersen J, Petersen LJ, Beurskens FJ, Schuurman J, van de Winkel JG, et al: Targeting interleukin-15 in patients with rheumatoid arthritis: A proof-of-concept study. Arthritis Rheum 52: 2686-2692, 2005.

30. Iftimie G, Stanescu A, Iancu M, Stoian A, Hainarosie R, Socea B, Isvoranu G, Marcu D, Neagu TP and Diaconu CC: The importance of early arthritis in patients with rheumatoid arthritis. J Mind Med Sci 5: 176-183, 2018.

31. Kivisäkk P, Matusevicius D, He B, Söderström M, Fredrikson S and Link H: IL-15 mRNA expression is up-regulated in blood and cerebrospinal fluid mononuclear cells in multiple sclerosis (MS). Clin Exp Immunol 111: 193-197, 1998.

32. Rentzos M, Cambouri C, Rombos A, Nikolaou C, Anagnostouli M, Tsoutsou A, Dimitrakopoulos A, Triantafyllou $\mathrm{N}$ and Vassilopoulos D: IL-15 is elevated in serum and cerebrospinal fluid of patients with multiple sclerosis. J Neurol Sci 241: 25-29, 2006.

33. Robinson TO and Schluns KS: The potential and promise of IL-15 in immuno-oncogenic therapies. Immunol Lett 190: 159-168, 2017.

34. Waldmann TA. Interleukin-15 in the treatment of cancer. Expert Rev Clin Immunol 10: 1689-1701, 2014.

35. Zhang X, Sun S, Hwang I, Tough DF and Sprent J: Potent and selective stimulation of memory-phenotype $\mathrm{CD}^{+} \mathrm{T}$ Cells in vivo by IL-15. Immunity 8: 591-599, 1998.

36. Waldmann TA, Lugli E, Roederer M, Perera LP, Smedley JV, Macallister RP, Goldman CK, Bryant BR, Decker JM, Fleisher TA, et al: Safety (toxicity), pharmacokinetics, immunogenicity, and impact on elements of the normal immune system of recombinant human IL-15 in rhesus macaques. Blood 117: 4787-4795, 2011

37. Stoklasek TA, Schluns KS and Lefrançois L: Combined IL-15/IL-15Ralpha immunotherapy maximizes IL-15 activity in vivo. J Immunol 177: 6072-6080, 2006.

38. Isvoranu G, Marinescu B, Surcel M, Ursaciuc C and Manda G: Immunotherapy in cancer-in vivo study of the antitumor activity of the IL-15/IL-15R alfa combination in an experimental model of melanoma. Farmacia 63: 631-636, 2015.

39. Zeng R, Spolski R, Finkelstein SE, Oh S, Kovanen PE, Hinrichs CS, Pise-Masison CA, Radonovich MF, Brady JN, Restifo NP, et al: Synergy of IL-21 and IL-15 in regulating CD8 ${ }^{+}$ $\mathrm{T}$ cell expansion and function. J Exp Med 201: 139-148, 2005.

40. Romee R, Rosario M, Berrien-Elliott MM, Wagner JA, Jewell BA, Schappe T, Leong JW, Abdel-Latif S, Schneider SE, Willey S, et al: Cytokine-induced memory-like natural killer cells exhibit enhanced responses against myeloid leukemia. Sci Transl Med 8: 357ra123, 2016.

41. Zhang M, Wen B, Anton OM, Yao Z, Dubois S, Ju W, Sato N, DiLillo DJ, Bamford RN, Ravetch JV and Waldmann TA: IL-15 enhanced antibody-dependent cellular cytotoxicity mediated by NK cells and macrophages. Proc Natl Acad Sci USA 115: E10915-E10924, 2018.

42. Robert H: Vonderheide: CD40 agonist antibodies in cancer Immunotherapy. Annu Rev Med 71: 47-58, 2020.

43. Winograd R, Byrne KT, Evans RA, Odorizzi PM, Meyer AR, Bajor DL, Clendenin C, Stanger BZ, Furth EE, Wherry EJ and Vonderheide RH: Induction of T-cell immunity overcomes complete resistance to PD-1 and CTLA-4 blockade and improves survival in pancreatic carcinoma. Cancer Immunol Res 3: 399-411, 2015.

44. Byrne KT and Vonderheide RH: CD40 Stimulation obviates innate sensors and drives T cell immunity in cancer. Cell Rep 15: 2719-2732, 2016.

45. Li DK and Wang W: Characteristics and clinical trial results of agonistic anti-CD 40 antibodies in the treatment of malignancies. Oncol Lett 20: 176, 2020.

46. Van Audenaerde JR, Marcq E, von Scheidt B, Davey AS, Oliver AJ, De Waele J, Quatannens D, Van Loenhout J, Pauwels P, Roeyen G, et al: Novel combination immunotherapy for pancreatic cancer: Potent anti-tumor effects with CD40 agonist and interleukin-15 treatment. Clin Transl Immunology 9: e1165, 2020.

47. Zhang M, Ju W, Yao Z, Yu P, Wei BR, Simpson RM, Waitz R, Fassò M, Allison JP and Waldmann TA: Augmented interleukin IL-15R $\alpha$ expression by CD40 activation is critical in synergistic CD8 T-cell mediated antitumor activity of anti-CD40 antibody with IL-15 in TRAMP-C2 tumors in mice. J Immunol 188: 6156-6164, 2012

48. Perez CR and De Palma M: Engineering dendritic cell vaccines to improve cancer immunotherapy. Nat Commun 10: 5408, 2019. 
49. Palucka K and Banchereau J: Dendritic cell-based cancer therapeutic vaccines. Immunity 39: 38-48, 2013.

50. Anguille S, Lion E, Van den Bergh J, Van Acker HH, Willemen Y, Smits EL, Van Tendeloo VF and Berneman ZN: Interleukin-15 dendritic cells as vaccine candidates for cancer immunotherapy. Hum Vaccines Immunother 9: 1956-1961, 2013.

51. Van Acker HH, Anguille S, De Reu H, Berneman ZN, Smits EL and Van Tendeloo VF: Interleukin-15-cultured dendritic cells enhance anti-tumor gamma delta T cell functions through IL-15 Secretion. Front Immunol 9: 658, 2018.

52. Zhu X, Marcus WD, Xu W, Hi L, Han K, Egan JO, Yovandich JL, Rhode PR and Wong HC: Novel human Interleukin15 agonists. J Immunol 183: 3598-3607, 2009.

53. Xu W, Jones M, Liu B, Zhu X, Johnson CB, Edwards AC, Kong L, Jeng EK, Han K, Marcus WD, et al: Efficacy and mechanism-of-action of a novel superagonist interleukin-15: Interleukin-15 receptor $\alpha \mathrm{Su} / \mathrm{fc}$ fusion complex in syngeneic murine models of multiple myeloma. Cancer Res 73: 3075-3086, 2013.

54. Hu Q, Ye X, Qu X, Cui D, Zang L, Xu Z, Wan H, Zhang L and Tao W: Discovery of a novel IL-15 based protein with improved developability and efficacy for cancer immunotherapy. Sci Rep 8: 7675,2018

55. Rhode PR, Egan JO, Xu W, Hong H, Webb GM, Chen X, Liu B, Zhu X, Wen J, You L, et al: Comparison of the superagonist complex, ALT-803, to IL15 as cancer immunotherapeutics in animal models. Cancer Immunol Res 4: 49-60, 2016.

56. Margolin K, Morishima C, Velcheti V, Miller JS, Lee SM, Silk AW, Holtan SG, Lacroix AM, Fling SP, Kaiser JC, et al: Phase I trial of ALT-803, a novel recombinant Interleukin-15 complex, in patients with advanced solid tumors. Clin Cancer Res 24: 5552-5561, 2018.

57. Romee R, Cooley S, Berrien-Elliott MM, Westervelt P, Verneris MR, Wagner JE, Weisdorf DJ, Blazar BR, Ustun C, DeFor TE, et al: First-in-human phase 1 clinical study of the IL-15 superagonist complex ALT-803 to treat relapse after transplantation. Blood 131: 2515-2527, 2018.

58. Knudson KM, James W, Hodge JW, Schlom J and Gameiro SR: Rationale for IL-15 superagonists in cancer immunotherapy. Expert Opin Biol Ther 20: 705-709, 2020.

59. Waldmann TA, Dubois S, Miljkovic MD and Conlon KC: IL-15 in the combination immunotherapy of cancer. Front Immunol 11, $868,2020$.

60. Mortier E, Quemener A, Vusio P, Lorenzen I, Boublink Y, Grötzinger J,Plet A and Jacques Y: Soluble interleukin-15 receptor alpha (IL-15R alpha)-sushi as a selective and potent agonist of IL-15 action through IL-15R beta/gamma. Hyperagonist IL-15 x IL-15R alpha fusion proteins. J Biol Chem 281: 1612-1619, 2006.

61. Desbois M, Le Vu P, Coutzac C, Marcheteau E, Béal C, Terme M, Gey A, Morisseau S, Teppaz G, Boselli L, et al IL-15 trans-signaling with the superagonist RLI promotes Effector/Memory CD8 $+\mathrm{T}$ cell responses and enhances antitumor activity of PD-1 antagonists. J Immunol 197: 168-178, 2016.

62. Gajewski TF, Schreiber H and Fu YX: Innate and adaptive immune cells in the tumor microenvironment. Nat Immunol 14 1014-1022, 2013.

63. Qing Y, Li Q, Ren T, Xia W, Peng Y, Liu GL, Luo H, Yang YX, Dai XY, Zhou SF and Wang D: Upregulation of PD-L1 and APE1 is associated with tumorigenesis and poor prognosis of gastric cancer. Drug Des Devel Ther 9: 901-909, 2015.

64. Postow MA, Callahan MK and Wolchok JD: Immune checkpoint blockade in cancer therapy. J Clin Oncol 33: 1974-1982, 2015.

65. Robert C, Schachter J, Long GV, Arance A, Grob JJ, Mortier L, Daud A, Carlino MS, McNeil C, Lotem M, et al: Pembrolizumab versus ipilimumab in advanced melanoma. N Engl J Med 372: 2521-2532, 2015

66. Carbone DP, Reck M, Paz-Ares L, Creelan B, Horn L, Steins M, Felip E, van den Heuvel MM, Ciuleanu TE, Badin F, et al: First-line nivolumab in stage IV or recurrent non-small-cell lung cancer. New Eng J Med 376: 2415-2426, 2017.

67. Bellmunt J, de Wit R, Vaughn DJ, Fradet Y, Lee JL, Fong L, Vogelzang NJ, Climent MA, Petrylak DP, Choueiri TK, et al: Pembrolizumab as second-line therapy for advanced urothelial carcinoma. New Eng J Med 376: 1015-1026, 2017.

68. Mathios D, Park CK, Marcus WD, Alter S, Rhode PR, Jeng EK, Wong HC, Pardoll DM and Lim M: Therapeutic administration of IL-15 superagonist complex ALT-803 leads to long-term survival and durable antitumor immune response in a murine glioblastoma model. Int J Cancer 138: 187-194, 2016.
69. KimPS,Kwilas AR, Xu W,AlterS,JengEK, Wong HC,Scholm Jand Hodge JW: IL-15 superagonist/IL-15R $\alpha$ Sushi-fc fusion complex (IL-15SA/IL-15R $\alpha$ Su-Fc; ALT-803) markedly enhances specific subpopulations of $\mathrm{NK}$ and memory $\mathrm{CD} 8^{+} \mathrm{T}$ cells, and mediates potent anti-tumor activity against murine breast and colon carcinomas. Oncotarget 7: 16130-16145, 2016.

70. Knudson KM, Hicks KC, Alter S, Schlomand J and Gameiro SR: Mechanisms involved in IL-15 superagonist enhancement of anti-PD-L1 therapy. J Immunother Cancer 7: 82, 2019.

71. Bartlett DL, Liu Z, Sathaiah M, Ravindranathan R, Guo Z, He Y and Guo ZS: Oncolytic viruses as therapeutic cancer vaccines. Mol Cancer 12: 103, 2013.

72. Stephenson KB, Barra NG, Davies E, Ashkar AA and Lichty BD: Expressing human interleukin-15 from oncolytic vesicular stomatitis virus improves survival in a murine metastatic colon adenocarcinoma model through the enhancement of anti-tumor immunity. Cancer Gene Ther 19: 238-246, 2012.

73. Tosic V, Thomas DL, Kranz DM, Liu J, McFadden G, Shisler JL, MacNeill AL and Roy EJ: Myxoma virus expressing a fusion protein of interleukin-15 (IL-15) and IL-15 receptor alpha has enhanced antitumor activity. PLoS One 9: e109801, 2014.

74. Kowalsky SJ, Liu Z, Feist M, Berkey SE, Ma C, Ravindranathan R, Dai E, Roy EJ, Guo ZS and Bartlett DL: Superagonist IL-15-armed oncolytic virus elicits potent antitumor immunity and therapy that are enhanced with PD-1 blockade. Mol Ther 26: 2476-2486, 2018.

75. Rosenberg SA, Yang JC, White DE and Steinberg SM: Durability of complete responses in patients with metastatic cancer treated with high-dose interleukin-2: Identification of the antigens mediating response. Ann Surg 228: 307-319, 1998

76. Schwartz RN, Stover L and Dutcher JP: Managing toxicities of high-dose interleukin-2. Oncology 16: 11-20, 2002.

77. Berger C, Berger M, Hackman RC, Gough M, Elliott C, Jensen MC and Riddell SR: Safety and immunologic effects of IL-15 administration in nonhuman primates. Blood 114: 2417-2426, 2009.

78. Conlon KC, Potter EL, Pittaluga S, Lee CR, Miljkovic MD, Fleisher TA, Dubois S, Bryant BR, Petrus MN, Perera LP, et al: IL15 by Continuous intravenous infusion to adult patients with solid tumors in a phase I trial induced dramatic NK-cell subset expansion. Clin Cancer Res 25: 4945-4954, 2019.

79. Conlon KC, Lugli E, Welles HC, Rosenberg SA, Fojo AT, Morris JC, Fleisher TA, Dubois SP, Perera LP, Stewart DM, et al: Redistribution, hyperproliferation, activation of natural killer cells and CD8 T cells, and cytokine production during first-in-human clinical trial of recombinant human Interleukin-15 in patients with cancer. J Clin Oncol 33: 74-82, 2015.

80. Wrangle JM, Velcheti V, Patel MR, Garrett-Mayer E, Hill EG, Ravenel JG, Miller JS, Farhad M, Anderton K, Lindsey K, et al: ALT-803, an IL-15 superagonist, in combination with nivolumab in patients with metastatic non-small cell lung cancer: A non-randomised, open-label, phase 1b trial. Lancet Oncol 19: 694-704, 2018.

81. Huang J, Schisler J, Wong HC, Rosser CJ and Sterbis J: Intravesical ALT-803 for BCG-unresponsive bladder cancer-A Case Report. Uro Case Rep 14: 15-17, 2017.

82. ImmunityBio granted FDA Breakthrough therapy designation for N-803 Il-15 superagonist in non-muscle invasive bladder cancer. News release. BioSpace. December 4, 2019. http://bit. ly/2ZgGAvM

83. Desbois M, Béal C, Charrier M, Besse B, Meurice G, Cagnard N, Jacques Y, Béchard D, Cassard L and Chaput N: IL-15 superagonist RLI has potent immunostimulatory properties on NK cells: Implications for antimetastatic treatment. J Immunother Cancer 8: e000632, 2020

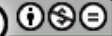

This work is licensed under a Creative Commons Attribution-NonCommercial-NoDerivatives 4.0 International (CC BY-NC-ND 4.0) License. 